\title{
COST725 - establishing a European phenological data platform for climatological applications: major results
}

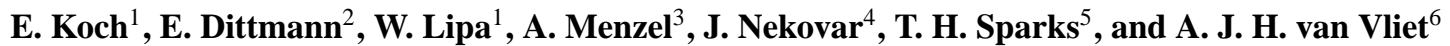 \\ ${ }^{1}$ Zentralanstalt für Meteorologie und Geodynamik, Vienna, Austria \\ ${ }^{2}$ Deutscher Wetterdienst, Offenbach, Germany \\ ${ }^{3}$ Technische Universität München, Center of Life and Food Sciences Weihenstephan, Freising, Germany \\ ${ }^{4}$ Czech Hydrometeorological Institute, Prague, Czech Republic \\ ${ }^{5}$ Poznan University of Life Sciences, Poznan, Poland \\ ${ }^{6}$ Environmental Systems Analysis Group, Wageningen University, The Netherlands
}

Received: 17 August 2009 - Revised: 7 September 2009 - Accepted: 10 September 2009 - Published: 13 October 2009

\begin{abstract}
COST - European COoperation in the field of Scientific and Technical Research - is the oldest and widest intergovernmental European network for cooperation in research. COST Action 725 (running from 2004 to 2009) aimed at and succeeded in establishing a European data base of phenological observations, classifying the data according to one common system and using the data in scientific peer reviewed papers. COST725 organized many workshops and conferences that helped to bring together not only the European, but also the global, phenological community. One of the highlights of COST725 was the boxed entry "Phenological responses to climate in Europe: the COST725 project" in the AR4 of IPCC in 2007. And last, but not least, although the action ended in April 2009 a follow up will be launched in 2010 under EUMETNET/ECSN.
\end{abstract}

\section{Introduction}

In the 19th century phenological recording was a traditional activity, but interest in observation declined in the early 20 th century. However, in recent decades, phenology has rapidly become an important tool for climate change impact studies and COST725 contributed significantly to this renewed interest. The phenological responses of plants to climate warming are very strong in temperate and cool climate zones (Menzel et al., 2006). Furthermore phenological change is relatively easy to identify, especially in comparison with changes to distribution, fecundity, population size, morphology etc. In Europe, where the strongest and most widespread tradition of phenological monitoring is found, widespread phenological observations, especially in plants, existed, but were collected and archived by many different organisations with different data policies, data formats etc. Observation rules were only partly comparable and differing lengths of time-series made work on the data at a European wide level quite difficult. This was the starting point for COST725 (Koch et al., 2005).

\section{Results}

\subsection{The history and present status of plant phenology in Europe (Nekováŕ et al., 2008)}

This book, summarising the history and current status of phenology in Europe, will be a valuable reference for phenological researchers for many years to come; it is the first time that such an extensive summary has been compiled. It is also available for free download at http://topshare.wur. $\mathrm{nl} /$ cost725/70987. The book contains contributions from all 27 COST725 members plus Croatia, Bosnia and Herzegovina, Montenegro and the International Phenological Gardens. A chapter on old international phenological networks completes the presentation of the extant national European networks (Fig. 1).

In fall 2008 a workshop on the benefit of old phenological series was organized in Rome with 22 oral presentations. The workshop proceedings are available in a special issue of The Italian Journal of Agrometeorology/Rivista Italiana di Agrometeorologia published in 2009.

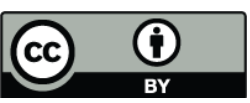

Correspondence to: $\mathrm{E}$. Koch

(e.koch@zamg.ac.at) 
Obfervationes Manheimenfes Botanicae \& propagationis Incolarum.

Hae obfervationes ad eum modum inftitutae funt, quem fupra (pag. 49) indicavimus. Quae hoc anno in hac parte defiderantur, ea explere futuris temporibus conabimur. Obfervationes botanicas in acceptis referimus indefeffo naturae fpeculatori Ferdinando Denis, artis machinariae magiftro centurioni palatino, a quo etiam Rheni obfervationes habemus. Catalogum natorum \& denatorum chriftianorum a parochis urbis, nobis amicifimis, Anabaptiftarum vero \& Judaeorum curis illuftriffimi baronis de VENNINGEN, Regiminis palatini praefidis, accepimus. Defcriptionem morborum vir celeberrimus ac doctiffimus FRANCISCUS MAY, medicinae doctor, confilii medici palatini affeffor \&c, humaniffime nobis fubminiftravit.

Obferv. Manheimenf. Botanicae.

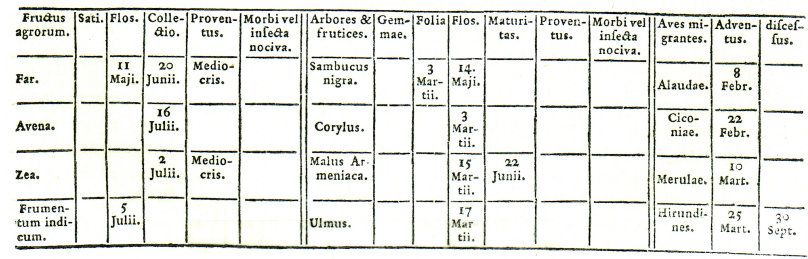

124 OBSERV. MANHEIM. BOTANICAE.

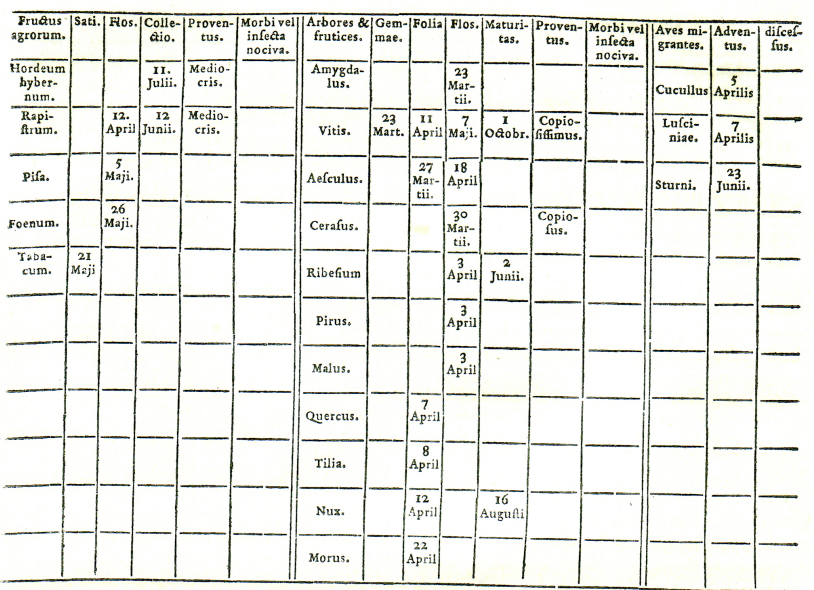

Figure 1. EPHEMERIDES of the SOCIETATIS METEOROLOGICAE PALATINAE, first edition published in 1783 with phenological observations from Mannheim for 1781.

\subsection{The common database}

The outcome of a questionnaire on phenological metadata helped to build the structure of the common database of COST725. To make the entries in the database comparable COST725 members agreed to apply the BBCH scale (Meier, 1997) to all national phenological observations across Europe following the recommendations of Bruns and Vliet (2003). This was a very important step towards the unification and standardization of phenological observations. As a follow up COST725 members and invited experts developed "Guidelines for plant phenological observations". WCMP/WCP/WMO accepted these guidelines as a standard for phenological observations and published them at http://www.omm.urv.cat/documentation.html .

In 2009 the web portal of COST725 was opened with data download-facilities and a graphical presentation of phenological data (Lipa et al., 2009 and Fig. 2).

\subsection{COST725 "Meta analysis", a major contribution to IPCC, AR4, WG II report}

WG3 of COST725 published a meta analysis of European phenological data (Menzel et al., 2006). In the IPCC AR4 WG II report the COST725 study was one of the major contributions for the assessment of observed changes and responses in natural and managed systems, using $125000 \mathrm{ob}-$ servational series of 542 plant and 19 animal species in 21 European countries for the period 1971-2000. The aggregation of the time series revealed a strong signal across Europe of changing spring and summer phenology: Spring and summer exhibited a clear advance by 2.5 days/decade in Europe. Mean autumn trends were close to zero, but suggested more of a delay when the average trend per country was examined (1.3 days/decade). The patterns of observed changes in spring (leafing, flowering and animal phases) were spatially consistent and matched measured national warming across European countries; thus the phenological evidence quantitatively mirrors regional climate warming. About $80 \%$ of spring/summer phases were found to be advancing. The findings strongly support previous studies in Europe, confirming them as free from bias towards reporting global climate change impacts.

\subsection{CR Climate Research, Special 19, Vol. 39, Num-} ber 3, 2009 with Open Access (free downloads http://www.int-res.com/abstracts/cr/v39/n3/)

This special issue gives further examples of COST725 collaboration; nine papers are presented based on the work of 35 scientists from 12 countries dealing e.g. with long data series from Europe, examining for correlations between them and looking at temporal changes in both trends and temperature responsiveness. One paper examines changes in a number of potentially important summaries of daily temperature data, including thresholds and temperature accumulations. These show some clear changes in European temperatures, and maps of these put a spatial context on the change. Phenology in the Baltic countries of Latvia and Lithuania are the focus of a paper where the influence of the North Atlantic Oscillation and precipitation is also examined. Another study focuses on phenological change in flowering within Europe's last remaining primeval lowland forest. Change is apparent even in this pristine environment reminding us that the consequences of a changing climate extend beyond those areas directly modified by Man. A study within the European Alps looks at changes in phenology with increasing altitude and changes in phenology in relation to location, phase timing and human population density are looked at in a subsequent paper. A paper on Bayesian methods examining phenological changes in 2600 European series confirmed that recent phenological change has not been linear but rather has an abrupt change associated with rising temperature. Phenological trends were most marked in NW Europe. Higher tech 


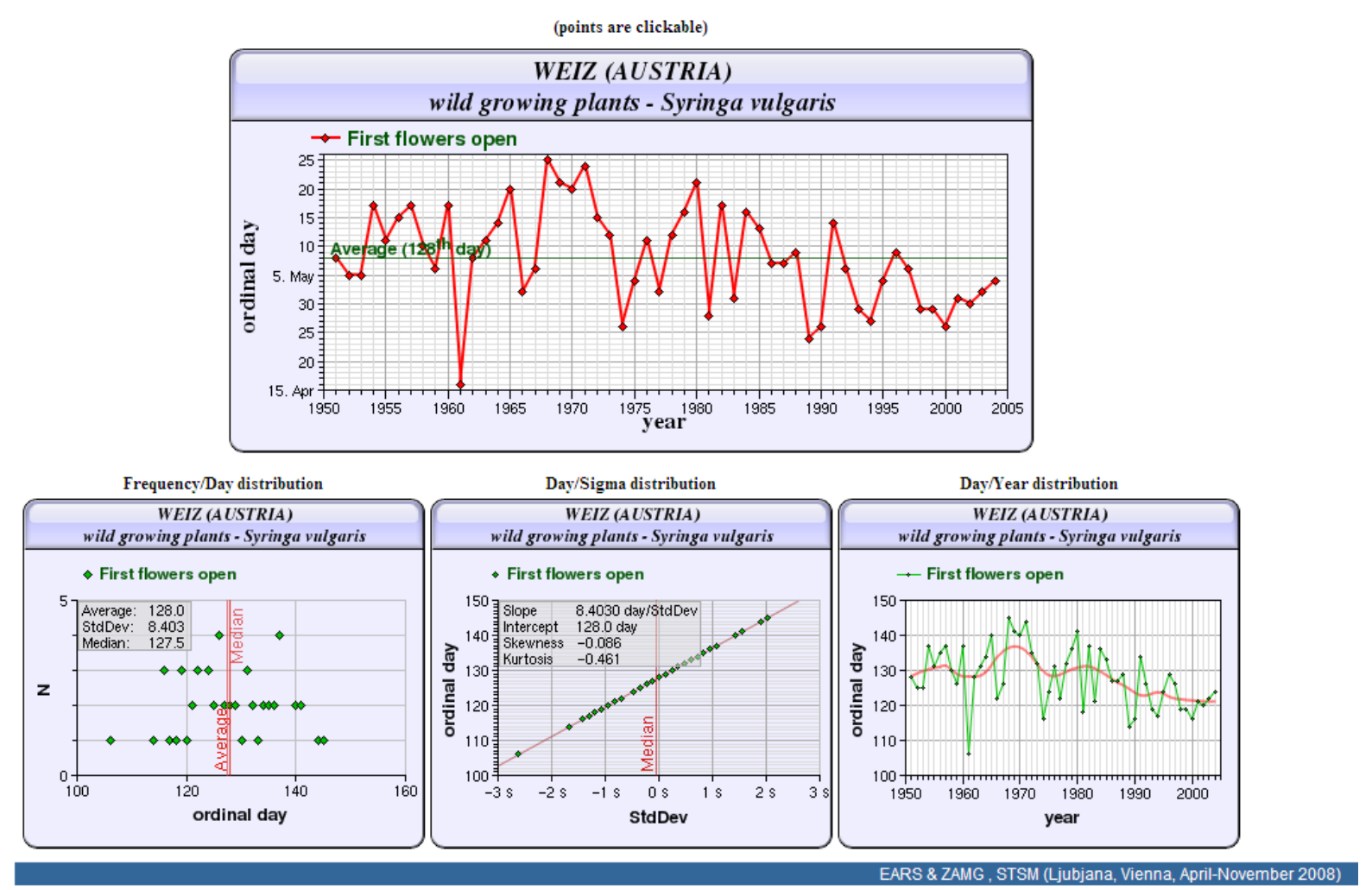

Figure 2. Graphic presentation of time series and some statistics from www.zamg.ac.at/cost725.

applications of phenology are considered in two papers. The use of digital photography on flux towers and the relationship between phenology and gross primary productivity are the major concerns of a Swiss study: different parts of the forest canopy were identified for examination of the development of individual tree species. The use of satellite imagery on a $8 \mathrm{~km}$ grid examines the beginning and end of the growing season in Fennoscandia and compares these data with local records of Betula phenology: though changes in the growing season over the study area are heterogeneous on average a 6 day/decade lengthening of the growing season was detected.

\section{Conclusions}

Over the last decade the barriers towards phenological collaboration between European countries have been broken down. COST725 has made a substantial contribution to that collaboration. The importance of phenological recording has been made very clear to those countries/organisations considering cutting back their programmes. New schemes, for example in the Republic of Ireland and Sweden, have been inspired by this work, and a revival of former networks is underway in Poland and Hungary. The prospects for increased phenological research have never looked so encouraging.
Acknowledgements. The authors and all COST725 members want to express their thanks to COST, the European COoperation in the field of Scientific and Technical Research, and especially its scientific officers P. Nejedlik, E. P. de Rose and C. Petite.

Edited by: E. Koch

Reviewed by: two anonymous referees

\section{References}

Bruns, E. and Vliet, v. A. J. H.: Standardisation of phenological monitoring in Europe, Wageningen University and DWD, 2003.

Koch, E., Dittmann, E., Lipa, W., Menzel, A., Nekovar, J., and Vliet, v. A. J. H.: Cost725 establishing a European phenological data platform. Proceedings of the European Geosciences Union, General Assembly 2005, Vienna, Austria, 24-29 April 2005.

Lipa, W. (chair of WG2), Baksiene, E., Behrendt, J., Briede, A., Chuine, I., Defila, C., Donnelly, A., Habič, B., Jatczak, K., Koch, E., Langvall, O., Jakubíková, V., Måge, F., Meier, D., Mulder, S., Nekovár̆, J., Nordli, Ø., Romanovskaja, D., Seguin, B., Sušnik, A., Zach-Hermann, S., Zimmermann, K. (vice-chairperson, WG 2), Žust, A.: Evolution of a database for European phenological data, in: Final Scientific Report of COST 725 Establishing a European Phenological dataplatform for climatological applications, edited by: E. Koch et al., ISBN 978-92-898-0048-8, 82 pp., COST office, 2009.

Meier, U.: Growth Stages of Mono- and Dicotyledonous Plants, Blackwell Wissenschaftsverlag, 1997. 


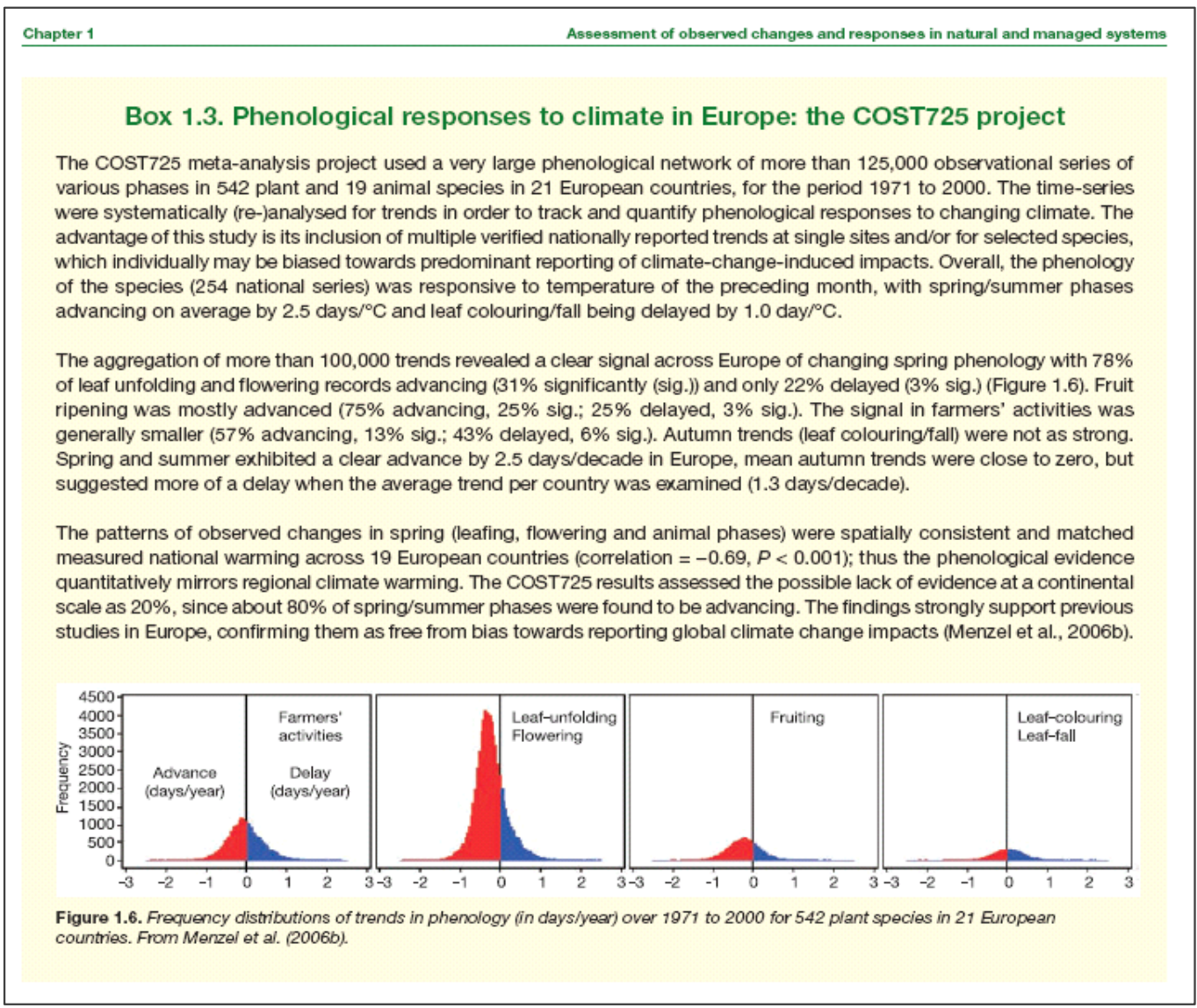

Figure 3. Box showing results of COST725 data analyses of Menzel et al. (GCB 2006), published in AR4 WGII chapter 1 IPCC 2007 (Rosenzweig et al., 2007).

Menzel, A., Sparks, T. H., Estrella, N., Koch, E., Aasa,A., Ahas, R., Alm-Kübler, K., Bissolli, P., Braslavská, O., Briede, A., Chmielewski, F.-E., Crepinsek, Z., Curnel, Y., Dahl, Å., Defila, C., Donnelly, A., Filella, Y., Jatczak, K., Måge, F., Mestre, A., Nordli, Ø., Peñuelas, J., Pirinen, P., Remisová, V., Scheifinger, H., Striz, M., Susnik, A., Wielgolaski, F.-E., Vliet, A. v., Zach, S., and Zust, A.: European phenological response to climate change matches the warming pattern, Global Change Biol., 12, 1969-1976, 2006.

Nekovář, J., Koch, E., Kubin, E., Nejedlik, P., Sparks, T. H., and Wielgolaski, F. E. (Eds.): The history and current status of plant phenology in Europe, ISBN 978-951-40-2091-9, 182 pp., Printed in Vammalan Kirjapaino Oy, 2008.
Rosenzweig, C., Casassa, G., Karoly, D.J., Imeson, A., Liu, C., Menzel, A., Rawlins, S., Root, T. L., Seguin, B., and Tryjanowski, P.: Assessment of observed changes and responses in natural and managed systems, Climate Change 2007: Impacts, Adaptation and Vulnerability, Contribution of Working Group II to the Fourth Assessment Report of the Intergovernmental Panel on Climate Change, edited by: Parry, M. L., Canziani, O. F., Palutikof, J. P., van der Linden, P. J., and Hanson, C. E., Cambridge University Press, Cambridge, UK, 79-131, 2007. 